\section{Influence of Window Details on the Energy Performance of an nZEB}

\section{Kristo Kalbe*, Targo Kalamees}

Tallinn University of Technology, Department of Civil Engineering and Architecture, Nearly Zero Energy Buildings Research Group, Ehitajate tee 5, Tallinn 19086, Estonia

*Corresponding author: kristo.kalbe@taltech.ee

\section{crosseg}

http://dx.doi.org/10.5755/j01.sace.24.1.22052

One of the largest sources of heat loss in buildings are the windows. However, windows are also important to increase solar heat gain and provide daylight. It is necessary to understand how window details influence the energy performance of very energy efficient houses. This is valuable information for the design decision making process and may lead to further research or product development. This paper examines the influence of window frame thermal transmittance, window frame width and window installation depth on the energy demand of the building. A single-family prefabricated timber nZEB located in Estonia was used as a reference building for this study. The results show that decreasing the thermal transmittance and width of the window frame have a remarkable effect on the energy demand of the nZEB (a variation of $42 \%$ and $25 \%$ respectively). The effect of optimising window installation depth is insignificant (ca 3\% variation of heat demand on most of the window placement range and up to 10\% of increase in heat demand when comparing the optimal placement to the least effective one). However, it can further improve the energy performance.

Keywords: energy performance of buildings, nZEB, timber construction, windows, window installation optimisation.

It is generally known that buildings account for the largest amount of energy consumption (Directive 2010/31/EU) and thus methods to reduce the energy demand of buildings are recommended.

Previous studies indicate that a large part of the heat loss in buildings occurs through the windows (Grynning et al. 2011). The energy balance of a window and the effect of window properties on the energy demand of a building is a complex interaction of a large array of parameters (Grynning et al. 2013). It is stated that when designing passive houses, a common technique is to let a large window area face south and to use small windows facing north to minimise the heat losses through the windows (Persson et al. 2006). Large windows towards the south help to increase the availability of solar heat gain. As stated by Winkler et al. (2017), the solar energy gains are among the most important aspects in the design of very low energy buildings like passive houses. Therefore, it is reasonable to research the possibilities of reducing the heat loss through windows or increase the solar gain.

As stated by Sadineni et al. (2011), there have been significant advances in glazing technologies and as brought out by Cuce and Riffat (2015), triple glazed low-e glazing can already have a thermal transmittance of only $0.28 \mathrm{~W} /\left(\mathrm{m}^{2} \cdot \mathrm{K}\right)$, which is nearing the recommended thermal transmittance

\section{Introduction}

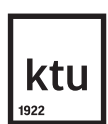

Journal of Sustainable Architecture and Civil Engineering Vol. 1 / No. 24 / 2019 pp. $61-70$ DOI 10.5755/j01.sace.24.1.22052 
value of $0.15 \mathrm{~W} /\left(\mathrm{m}^{2}\right.$. K) for passive house walls (Feist et al. 2005). There are also various state-ofthe art glazing technologies such as aerogel, vacuum and switchable reflective or suspended film glazing, which can further improve the energy efficiency of glazing (Sadineni et al. 2011).

Marino et al. (2017) stated that there have been numerous studies about the influence of fenestration on the building energy performance. There have been studies about the window-to-wall ratio and glazing properties (for example Bülow-Hübe 2001, Persson, Roos, and Wall 2006, Leskovar and Premrov 2011, Ihm et al. 2012, Susorova et al. 2013, Harmati and Magyar 2015). But the effect of window frame parameters is still less studied. It is necessary to understand whether the influence of window frames is significant in very efficient houses. This is valuable information for the design decision making process and may lead to further research or product development.

In a recent study, Misiopecki et al. (2018) investigated the window installation linear thermal transmittance (LTT) in various window installation methods and positions and found that the variation of the LTT is significant, but there was no further research on the effect of LTT on the overall energy demand nor on the effect of window position to the shading and thus on the availability of solar gains.

This study determines the influence of window frame details and the window installation depth on the energy demand of the building. Two parameters of the window frame were further examined - the window frame thermal transmittance and the width of the window frame. Additionally, an optimisation task was carried out to determine the influence of the window installation depth (influenced by the LTT and solar gain through the windows). It was hypothesised that the impact of window frame properties is significant on the energy balance of the nZEB. A single-family prefabricated timber nZEB located in Estonia was used as a reference building for this study.

\section{Methods}

\section{Energy balance simulations}

The energy balance simulations were done using the Passive House Planning Package - PHPP (Passive House Institute 2013), which utilises the simplified quasi-steady-state monthly method specified in ISO 13790:2008. The PHPP software has been validated with real-world projects within the CEPHEUS project and proved to be an accurate tool for energy balance simulations for passive house level buildings (Schnieders and Hermelink 2006). Additionally - the PHPP software allows detailed input of window reveal and overhang shading data, as well as the input of window frame installation LTT values for each of the window sides. The detailed shading data input allows the examination of the effect of window placement on the solar heat gains and thus on the heat demand. The PHPP user manual (Passive House Institute 2013) states that the algorithms used for the calculation are derived from dynamic building simulations (Feist 1998, Feist et al. 1998). The climate data used for the calculations is in accordance to the Estonian test reference year for energy calculations (Kalamees and Kurnitski 2006). All of the other boundary conditions are as required in the Estonian regulation of methodology for calculating the energy performance of buildings (RT I 19.01.2018; 7).

For the annual heat demand, the monthly values are added up, which are found by the following equation (Eq. 1.).

$$
Q_{H}=Q_{T}+Q_{V}-\eta \times\left(Q_{S}+Q_{I}\right)
$$

Where: $Q_{H}=$ heat demand, $\mathrm{kWh} / \mathrm{a} ; Q_{T}=$ total transmission losses (the values for each building element are summed), $\mathrm{kWh} / \mathrm{a} ; Q_{V}=$ ventilation losses, $\mathrm{kWh} / \mathrm{a} ; Q_{S}=$ solar heat gains, $\mathrm{kWh} / \mathrm{a} ; Q_{1}=$ internal heat gains, $\mathrm{kWh} / \mathrm{a} ; \mathrm{n}=$ gain utilisation factor.

$Q_{T}$ and $Q_{S}$ change when the window parameters are changed. $Q_{T}$ can be found by the average thermal transmittance of the whole building envelope or as a sum of the specific transmission 
losses of all the building envelope elements. By only changing the window frame parameters, the transmission losses of all the other building elements remain the same. Therefore, the method of summing the specific transmission losses for each element is more useful here. The equation for transmission losses for one building envelope element is as follows (Eq. 2.).

$$
Q_{T}=A \times U \times f_{t} \times G_{t}
$$

Where: $A=$ area of the building envelope element (e.g. the window frame), $m^{2} ; U=$ thermal transmittance coefficient of the building element (e.g. the thermal transmittance of the window frame with the installation thermal bridge effect included), $\mathrm{W} /\left(\mathrm{m}^{2} \cdot \mathrm{K}\right) ; f_{t}=$ temperature-correction factor; $G_{t}=$ heating degree hours, $\mathrm{kKh} / \mathrm{a}$.

By changing the window frame dimensions, the area of the transparent building elements or window glazing is changed, and the shading reduction factor is changed slightly. By changing the window frame placement in the walls, the change of shading reduction factor is more pronounced. The following equation (Eq. 3.) shows how the glazing area or reduction factor influence the amount of solar heat gains.

$$
Q_{S}=r \times g \times A \times G
$$

Where: $r$ = reduction factor for shading, dirt and non-perpendicular incident radiation; $g=$ SHGC total solar energy transmittance value; $A=$ total area of the transparent building elements, $\mathrm{m}^{2}$; $G=$ global solar irradiation as an average for the specific period, $\mathrm{kWh} /\left(\mathrm{m}^{2} \cdot \mathrm{a}\right)$.

\section{Two-dimensional heat transfer simulations and temperature factor calculation}

In order to determine the LTT of the window installation junctions, LBNL Therm 7.6 was used. It is a two-dimensional conduction heat transfer analysis tool based on finite-element method. The computational method is described more in depth in the Therm 7 simulation manual (LBNL 2017). The simulation was performed according to methods, conditions and assumptions specified in ISO 10211:2017, ISO 10077-1:2017, ISO 10077-2:2017 and ISO 6946:2017.

The LTT or Psi $(\Psi), W /(m \cdot K)$, for the window installation is found by the following equation (Eq. 4.).

$$
\Psi=L_{2 D}-U_{E W} \times l_{E W}-U_{W} \times l_{W}
$$

Where: $L_{2 D}=$ thermal coupling coefficient from the 2D simulation of the window installation junction, $\mathrm{W} /(\mathrm{m} \cdot \mathrm{K}) ; U_{E W}=$ thermal transmittance of the exterior wall in the model, $\mathrm{W} /\left(\mathrm{m}^{2} \cdot \mathrm{K}\right) ; l_{E W}=$ length of the exterior wall projection in the model, $\mathrm{m} ; U_{W}=$ thermal transmittance of the window product in the model, $\mathrm{W} /\left(\mathrm{m}^{2} \cdot \mathrm{K}\right) ; l_{W}=$ length of the window product projection in the model, $\mathrm{m}$.

The heat transfer simulation allows the determination of temperatures throughout the model and calculation of the temperature factor $\mathrm{f}_{\mathrm{Rsi}}$ (EN ISO 13788:2012) by the following equation (Eq. 5.).

$$
f_{R s i}=\frac{T_{s i}-T_{e}}{T_{i}-T_{e}}
$$

Where: $T_{s i}=$ temperature at the internal surface, ${ }^{\circ} \mathrm{C} ; T_{e}=$ outdoor air temperature, ${ }^{\circ} \mathrm{C} ; T_{i}=$ indoor air temperature, ${ }^{\circ} \mathrm{C}$.

To avoid mould growth on the thermal bridges, the minimal spot temperature factor should be $\mathrm{f}_{\mathrm{Rsi}}$ $\geq 0.80$ in the Estonian climate (Kalamees 2006).

\section{Reference building as built (nZEB) and as a low energy building (LEB)}

The reference building size and floor plan (Fig. 1) are representative to the average Estonian single-family house. The total heated area of the reference building is $148 \mathrm{~m}^{2}$. The building is designed 
according to the principles of the passive house method (Feist et al. 2005b) and, with the added photovoltaic system, it is also a nearly zero energy building (nZEB) according to the local regulations (RT I 05.06.2015; 15.). The building is located in the inland area of the Estonian climate (Kalamees and Kurnitski 2006). A mechanical ventilation system with heat recovery rate of up to $93 \%$ is utilised. The house is built with prefabricated timber elements with $500 \mathrm{~mm}$ of blown cellulose insulation in the walls $\left(\mathrm{U}=0.08 \mathrm{~W} /\left(\mathrm{m}^{2} \cdot \mathrm{K}\right)\right)$ and $600 \mathrm{~mm}$ of blown cellulose insulation on the roof $\left(\mathrm{U}=0.06 \mathrm{~W} /\left(\mathrm{m}^{2} \cdot \mathrm{K}\right)\right)$. The insulated timber elements are mounted on a concrete slab with $500 \mathrm{~mm}$ of XPS insulation underneath $\left(U=0.06 \mathrm{~W} /\left(\mathrm{m}^{2} \cdot \mathrm{K}\right)\right)$.

Fig. 1

Reference building view from southeast (left) and the firstfloor plan (right)
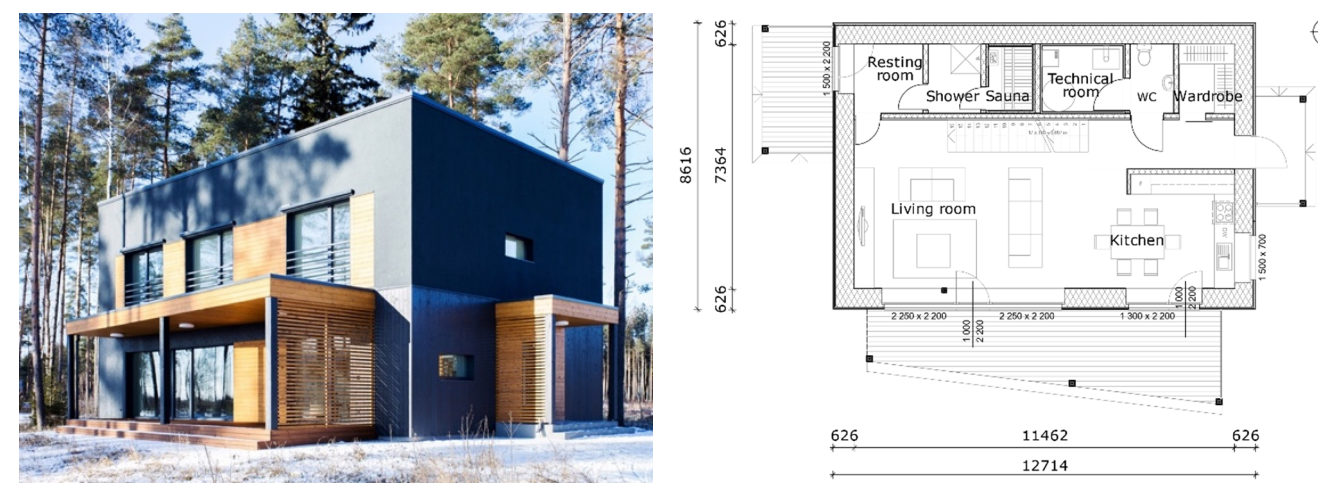

The windows in the reference building have wood-aluminium frames and triple low-e glazing. Further details of the installed windows are in Table 1. All the given information is also considered in the energy balance calculations.

Table 1

Reference building operable and fixed window frame parameters

\begin{tabular}{|c|c|c|c|c|c|c|c|c|c|}
\hline Window type & \multicolumn{5}{|c|}{ Operable } & \multicolumn{4}{|c|}{ Fixed } \\
\hline Frame section & Threshold & Bottom & Top & Lateral & Transom & Bottom & Top & Lateral & Transom \\
\hline Frame width $(\mathrm{mm})$ & 76 & 86 & 86 & 86 & 110 & 86 & 86 & 86 & 110 \\
\hline $\begin{array}{l}\text { Frame thermal } \\
\text { transmittance } \\
\left(\mathrm{W} /\left(\mathrm{m}^{2} \cdot \mathrm{K}\right)\right)\end{array}$ & 1.00 & 0.89 & 0.68 & 0.68 & 0.96 & 0.69 & 0.52 & 0.52 & 0.79 \\
\hline
\end{tabular}

The specific wood-aluminium window frames installed in the building are developed to be used in very efficient houses and have wood fibre insulation covering on the timber frame which in turn is suitable to be covered with additional insulation (for example the exterior wall insulation or wind barrier). In the reference building the window frames were covered with additional wood fibre insulation. See Fig. 2 for the detailed drawing of a typical junction. About $70 \%$ of the window area is facing towards the south - this is a common practice with energy efficient buildings designed for the northern hemisphere. Furthermore - the windows have few divisions to maximise the solar gain and minimise the heat loss through the window frames.

An additional model of the reference building was proposed to determine whether the effect of window frame parameters and the installation depth is specific to very efficient buildings. Thus, a model with reduced energy performance was proposed, with wall, roof and floor construction corresponding to typical prefabricated low-energy buildings (LEB) in Estonia. See Table 2 for the respective thermal transmittances. Everything else was left unchanged. The proposed wall construction for the LEB has an insulation layer of $195+45 \mathrm{~mm}$ as opposed to the wall construction of the 


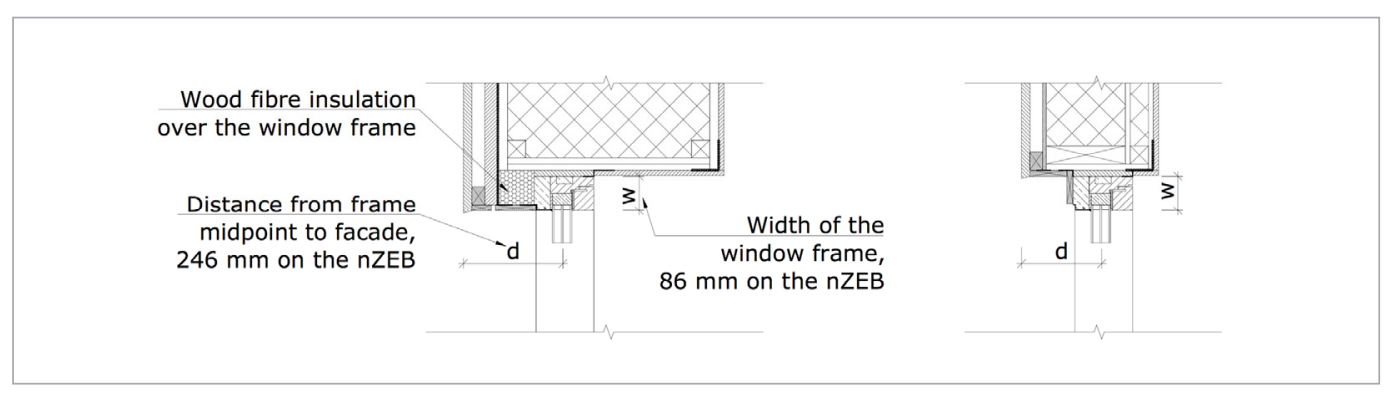

built nZEB which has $500 \mathrm{~mm}$ of insulation. The choice of the thinner wall also allows studying the effect of the window installation on different wall thicknesses. In Fig. 2 there is also the typical window installation junction of the LEB.

\begin{tabular}{c|c|c}
\hline \multirow{2}{*}{$\begin{array}{c}\text { Part of the thermal } \\
\text { envelope }\end{array}$} & \multicolumn{2}{|c}{ Thermal transmittance $\left(\mathrm{W} /\left(\mathrm{m}^{2} \cdot \mathrm{K}\right)\right)$} \\
\cline { 2 - 3 } & $\begin{array}{c}\text { Reference building as } \\
\text { built (nZEB) }\end{array}$ & $\begin{array}{c}\text { Reference building } \\
\text { as LEB }\end{array}$ \\
\hline External wall & 0.08 & 0.16 \\
\hline Roof & 0.06 & 0.07 \\
\hline Floor slab & 0.06 & 0.17 \\
\hline
\end{tabular}

\section{Analysis of the effect of window frame properties}

For determining the influence of the thermal transmittance of the window frames, a hypothetical window frame with homogeneous properties was proposed. The projected width of the frame section (marked as "w" in Fig. 2) of the window frame was chosen to be $11 \mathrm{~cm}$, which is a common value among contemporary windows. Only the $U_{f}$ value was incrementally changed from $0.5 \mathrm{~W} /\left(\mathrm{m}^{2} \cdot \mathrm{K}\right)$ to $1.4 \mathrm{~W} /\left(\mathrm{m}^{2} \cdot \mathrm{K}\right)$ in the energy balance simulations. Everything else was left unchanged.

For the sensitivity analysis of the influence of window frame width, w (see Fig. 2), to the energy balance a similar approach was used. Again - a hypothetical homogenous window frame was used in the simulations, but the $U_{f}$ value was left unchanged at $0.8 \mathrm{~W} /\left(\mathrm{m}^{2} \cdot \mathrm{K}\right)$, corresponding to good thermal quality and the frame width $(w)$ was incrementally changed from 5 to $14 \mathrm{~cm}$. In relation to that the glazing area and the shading reduction factor was changed.

The analysis was done for both the nZEB and LEB version of the reference building.

\section{Analysis of the effect of window installation}

To determine the influence of window installation depth, a series of simulations were done on the basis of the reference building both as nZEB and as LEB.

The window frame placement (the distance from the window frame midpoint to the façade plane, marked as "d" in Fig. 2) was incrementally changed in 14 steps from the outer edge to the inner edge of the window reveal. The steps were $30 \mathrm{~mm}$ for the nZEB and $10 \mathrm{~mm}$ for the LEB version of the building. For each step, a new energy balance calculation was done, considering the changed shading situation and changed window installation thermal bridge. Thus, heat-transfer simulations were carried out to determine the LTT or Psi values and temperature factor or $\mathrm{f}_{\mathrm{Rsi}}$ values for the top, side and bottom section of the window installation for each of the steps and for both versions of the building.

On Fig. 3 there is an excerpt of the simulated models for the top section of the window installation for both building versions in the extreme and middle positions of the window. On each of the positions depicted, there is also the corresponding window frame midpoint distance from the façade plane (d). As seen - for the nZEB version the distance variation is $39 \mathrm{~cm}$ from the outer extreme position to the inner extreme position and $13 \mathrm{~cm}$ for the LEB version. Thus, the innermost position on the nZEB version is more shaded than on the LEB version.
Fig. 2

Typical window installation junctions for the nZEB (left) and the LEB (right)

\section{Table 2}

Thermal envelope parameters of the nZEB and LEB versions of the reference building 
Fig. 3

Excerpt of the THERM models simulated to find window installation

LTT values

Results

Fig. 4

Energy balance of the reference building as built (nZEB level). Heat losses are on the left and gains on the right
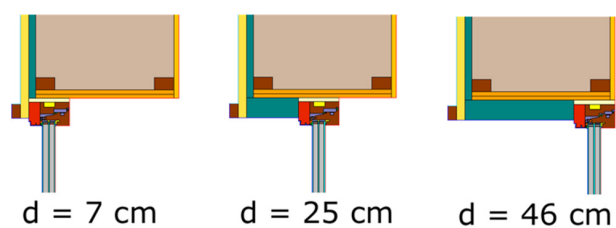

$\mathrm{d}=25 \mathrm{~cm}$

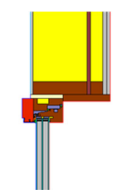

$\mathrm{d}=7 \mathrm{~cm}$

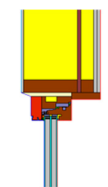

$\mathrm{d}=13 \mathrm{~cm}$

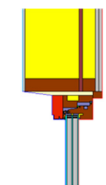

$\mathrm{d}=20 \mathrm{~cm}$

In Fig. 4 there is the annual energy balance of the reference building as built. It is observed that the heat loss through windows constitutes a large part of the total heat loss. However, the solar heat through windows contributes a large amount of the gains also and thereof is an important factor.

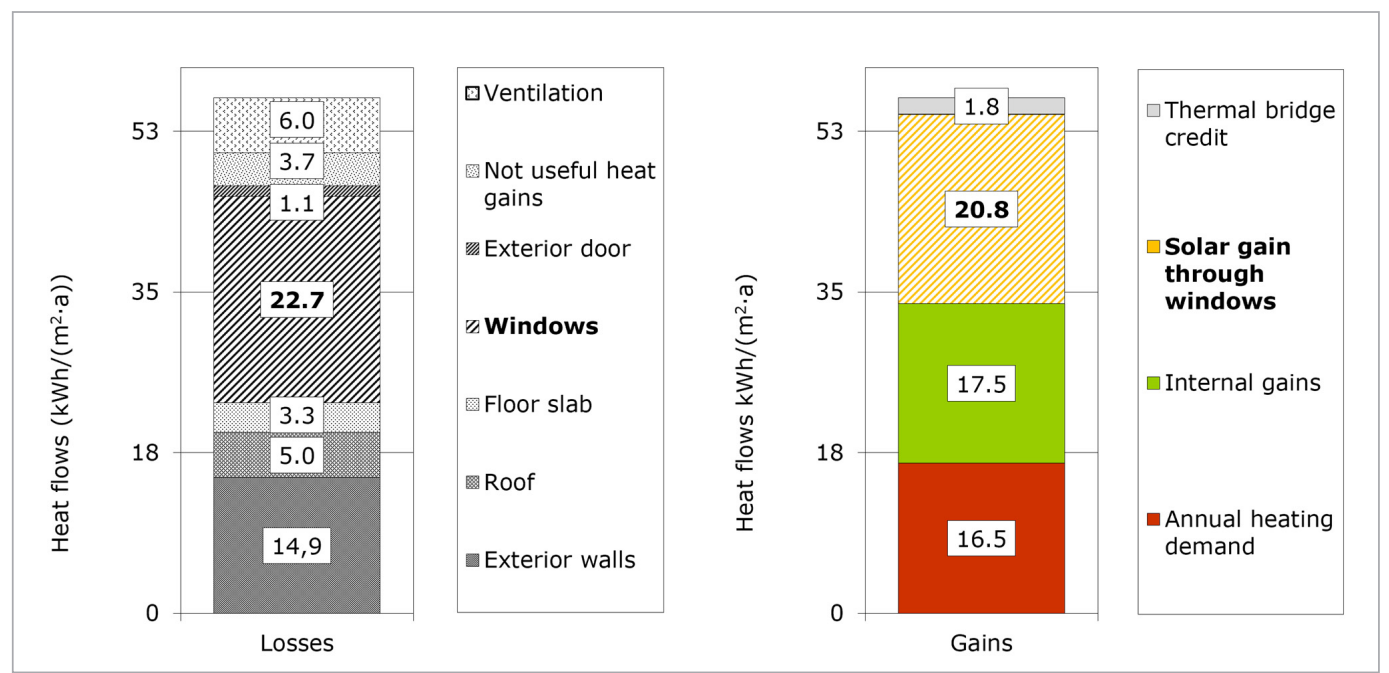

Increasing the window frame thermal transmittance from $0.5 \mathrm{~W} /\left(\mathrm{m}^{2} \cdot \mathrm{K}\right)$ to $1.4 \mathrm{~W} /\left(\mathrm{m}^{2} \cdot \mathrm{K}\right)$ increases the net heat demand by $42 \%$ on the nZEB version of the reference building (from 16.3 to $23.1 \mathrm{kWh} /$ $\left(\mathrm{m}^{2}\right.$.a)) and by $27 \%$ on the LEB version (from 29,6 to $37,5 \mathrm{kWh} /\left(\mathrm{m}^{2}\right.$.a)). See Fig. 5 for a graphical representation of the relation.

The variation of the window frame width $(\mathrm{w})$ from 5 to $14 \mathrm{~cm}$ results in the increase of the net heat demand from 15.8 to $19.8 \mathrm{kWh} /\left(\mathrm{m}^{2}\right.$.a) on the nZEB (increase of $25 \%$ ) and from 28.2 to $34.0 \mathrm{kWh} /$ $\left(\mathrm{m}^{2} \cdot \mathrm{a}\right)$ on the LEB (increase of $\left.21 \%\right)$. In Fig. 5 there is the corresponding relation.

Fig. 5

The influence of window frame thermal transmittance (left) and the window frame width (right) to the overall net heat demand of the two versions of the reference building

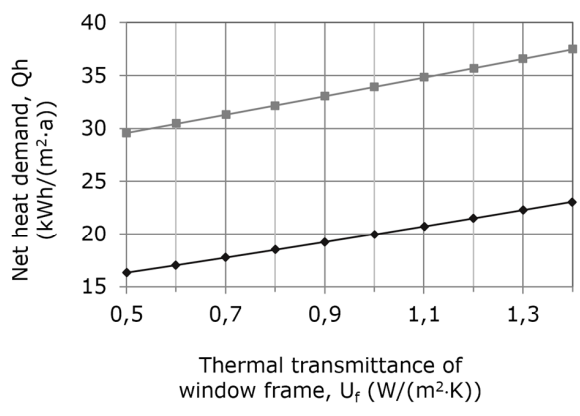

$\rightarrow$ nZEB net heat demand $\rightarrow$ LEB net heat demand

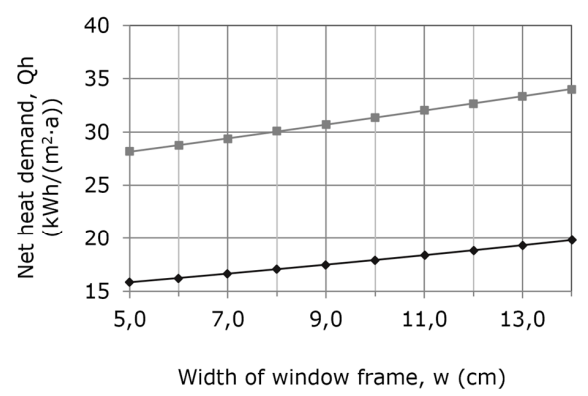

$\longrightarrow$ nZEB net heat demand $\longrightarrow$ LEB net heat demand 
In Table 3 there are the average $L T T$ values and the minimum $f_{R s i}$ values for each of the simulated positions for the nZEB version of the reference house. The $f_{R S i}$ values which meet the minimum requirement in the Estonian climate (Kalamees 2006) are marked with a light green background. In Table 4 there are the corresponding values for the LEB version of the house. The lowest $f_{R s i}$ values were on the bottom part of the window frame installation on both building versions. For the top and side part of the window installation, the $f_{R s i}$ values were above 0.80 for all of the window frame positions and thus were within the accepted limit. In Fig. 6 there is a graphical representation of the average $\Psi$ values.

\begin{tabular}{c|c|c|c|c|c|c|c|c|c|c|c|c|c|c}
\hline $\begin{array}{c}\mathrm{d}, \mathrm{mm} \& \\
\text { relative } \\
\text { installation } \\
\text { depth, } \%\end{array}$ & 7 & 10 & 13 & 16 & 19 & 22 & 25 & 28 & 31 & 34 & 37 & 40 & 43 & 47 \\
\hline $\begin{array}{c}\text { Average LTT, } \\
\mathrm{W} /(\mathrm{m} \cdot \mathrm{K})\end{array}$ & 0.047 & 0.044 & 0.042 & 0.040 & 0.038 & 0.037 & 0.036 & 0.036 & 0.036 & 0.037 & 0.039 & 0.041 & 0.044 & 0.050 \\
\hline $\begin{array}{c}f_{\text {Rsi }} \text { bottom } \\
\text { installation }\end{array}$ & 0.787 & 0.790 & 0.793 & 0.797 & 0.800 & 0.803 & 0.803 & 0.807 & 0.813 & 0.817 & 0.827 & 0.833 & 0.840 & 0.823 \\
\hline
\end{tabular}

\begin{tabular}{|c|c|c|c|c|c|c|c|c|c|c|c|c|c|c|}
\hline $\begin{array}{l}\mathrm{d}, \mathrm{mm} \& \\
\text { relative } \\
\text { installation } \\
\text { depth, } \%\end{array}$ & $\begin{array}{l}7 \\
0 \%\end{array}$ & $\begin{array}{l}8 \\
8 \%\end{array}$ & $\begin{array}{l}9 \\
15 \%\end{array}$ & $\begin{array}{l}10 \\
23 \%\end{array}$ & $\begin{array}{l}11 \\
31 \%\end{array}$ & $\begin{array}{l}12 \\
38 \%\end{array}$ & $\begin{array}{l}13 \\
46 \%\end{array}$ & $\begin{array}{l}14 \\
54 \%\end{array}$ & $\begin{array}{l}15 \\
62 \%\end{array}$ & $\begin{array}{l}16 \\
69 \%\end{array}$ & $\begin{array}{l}17 \\
77 \%\end{array}$ & $\begin{array}{l}18 \\
85 \%\end{array}$ & $\begin{array}{l}19 \\
92 \%\end{array}$ & $\begin{array}{l}20 \\
100 \%\end{array}$ \\
\hline $\begin{array}{l}\text { Average LTT } \\
\mathrm{W} /(\mathrm{m} \cdot \mathrm{K})\end{array}$ & 0.043 & 0.039 & 0.035 & 0.032 & 0.031 & 0.029 & 0.028 & 0.028 & 0.028 & 0.028 & 0.029 & 0.030 & 0.031 & 0.033 \\
\hline $\begin{array}{l}f_{R s i} \text { bottom } \\
\text { installation }\end{array}$ & 0.797 & 0.803 & 0.807 & 0.810 & 0.813 & 0.817 & 0.820 & 0.823 & 0.827 & 0.830 & 0.837 & 0.840 & 0.847 & 0.853 \\
\hline
\end{tabular}

The shading effect of the window reveal increases, when moving the window frame towards the interior. In Fig. 6 there is a chart to describe this effect on both the nZEB and LEB version.

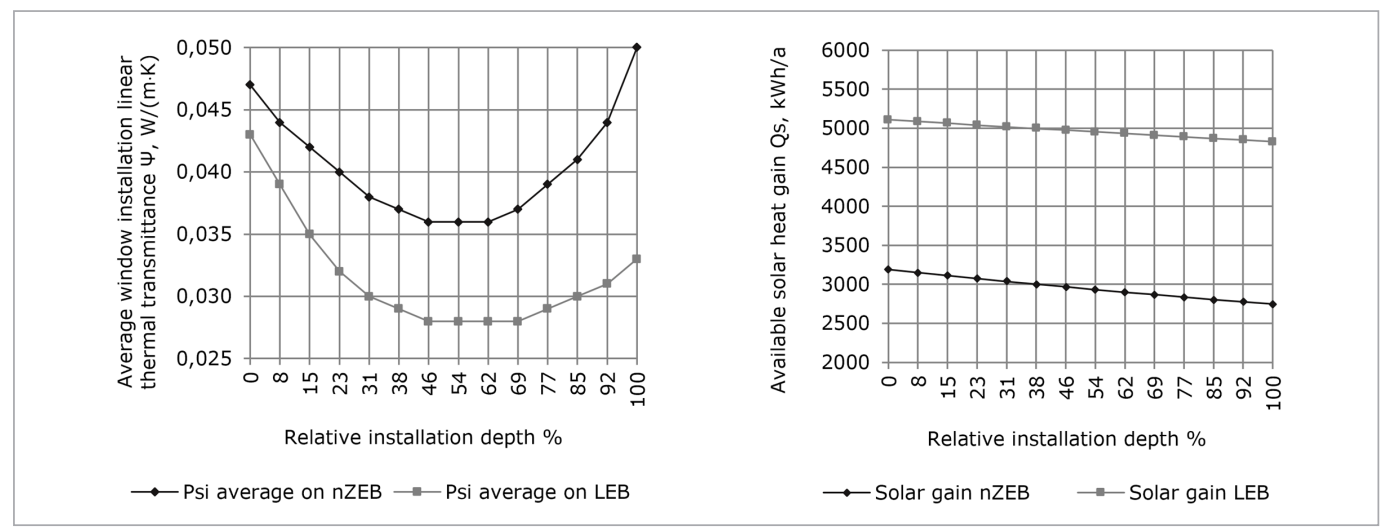

The maximum difference of the average window installation LTT is $0.014 \mathrm{~W} /(\mathrm{m} \cdot \mathrm{K})$ on the nZEB version and $0.015 \mathrm{~W} /(\mathrm{m} \cdot \mathrm{K})$ on the LEB version of the reference building. Considering the total length of window installation $(87.4 \mathrm{~m})$ and the amount of heating degree hours $(107,460 \mathrm{Kh})$ from the base model, the maximum saveable energy amount is $131,488 \mathrm{Wh}$ or $131.5 \mathrm{kWh}$ per year or $0.89 \mathrm{kWh} /\left(\mathrm{m}^{2}\right.$. a) on the nZEB. As the total amount of heat losses is $56.7 \mathrm{kWh} /\left(\mathrm{m}^{2} \cdot \mathrm{a}\right)$, the saveable amount by window frame installation optimisation is about $1.7 \%$. The corresponding amount on the LEB is about $1.08 \mathrm{kWh} /\left(\mathrm{m}^{2}\right.$. a) or $1.2 \%$ of the total heat loss of $87.2 \mathrm{kWh} /\left(\mathrm{m}^{2} \cdot \mathrm{a}\right)$.

The possible energy savings from the lower window installation LTT is however counteracted by the
Table 3

Average LTT and minimum $f_{R s i}$ values for the window installation junctions on the nZEB

\section{Table 4}

Average LTT and minimum $f_{R S i}$ values for the window installation junctions on the LEB

\section{Fig. 6}

The variation of the window installation LTT (left) and the available solar heat gain (right) in relation to the installation depth on both versions of the reference building 
decrease in solar gain. The amount of available solar heat gain decreases by $7.1 \%$ on the nZEB and $2.6 \%$ on the LEB when the installation depth of windows is changed from the outermost position to the relative depth of $46 \%$ (where the lowest LTT occurs).

In Fig. 7 there are graphs for the relation of the overall net heat demand to the window installation depth on both building versions. The points with minimum heat demand are marked with a red line on the figure.

The overall net heat demand varies from 16.6 to $18.2 \mathrm{kWh} /\left(\mathrm{m}^{2}\right.$. a) on the nZEB and from 28.6 to $29.4 \mathrm{kWh} /\left(\mathrm{m}^{2} \cdot \mathrm{a}\right)$ on the LEB. In the case of the nZEB, the variation in heat demand is only about $3 \%$ on the relative installation depth range of $0 . .69 \%$ and only on the innermost window position, the difference with the most effective position reaches 10\% (mostly due to decreased solar heat gain). On the LEB, the variation in heat demand is $3 \%$ within the whole installation depth range.

Fig. 7

The effect of window installation depth on the reference building heat demand (nZEB version on the left and LEB version on the right). The red lines mark the optimal installation depths
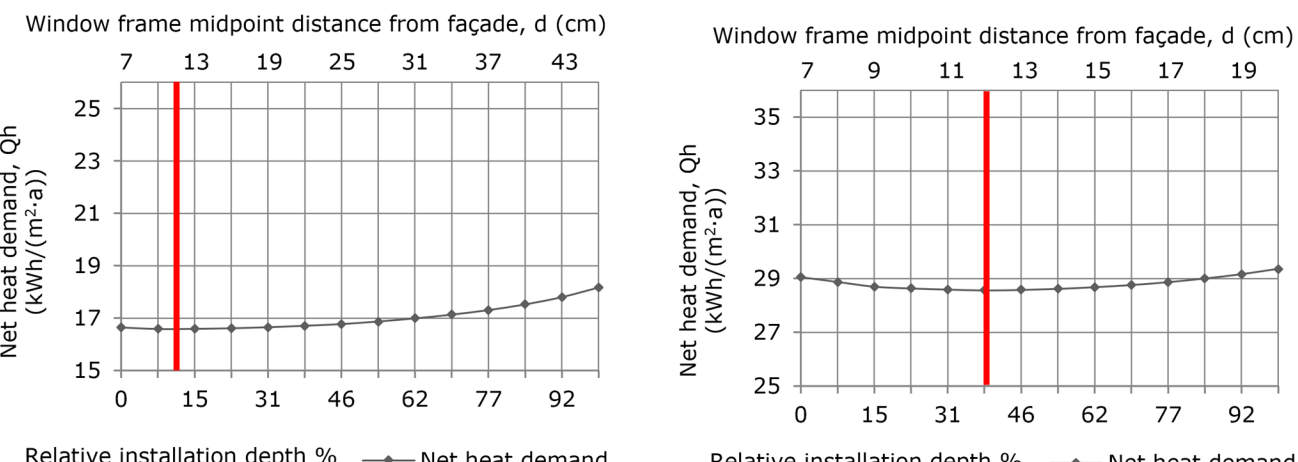

Relative installation depth \% $\longrightarrow$ Net heat demand

The results indicate that the window frame thermal transmittance and its dimensions indeed influence the overall energy balance of the nZEB by a noticeable margin (over 40\%). The effect is less significant on the LEB, which indicates that the window frames gain more importance in the overall energy balance as the net heat demand of the building decreases. It follows from this that from a design decision making point of view, the actual window frame product is important. Moreover - the window frame width is also important - the net heat demand increases over $20 \%$ on both the nZEB and LEB versions of the building when the frame width is changed from very shallow to slightly larger than regular. Thus, it is not advisable to compare window products by only comparing the total thermal transmittance, as the effect of window frame width to solar heat gain is also noticeable.

When only considering the net heat demand, the lowest thermal transmittance and the smallest frame dimensions are preferred, but the increased solar gain might also contribute to overheating. Thus, further investigation is applicable to determine design decision making recommendations from the overheating point of view and taking both the heat demand and overheating issues into account. Nonetheless - this study shows that the window frame product and its properties should be included in detail to the energy performance calculations of nZEBs.

Concerning the window installation LTT, the results are in conjunction with the study by Misiopecki et al. (2018). It is observed that the lowest window installation LTT values are achieved for window positions roughly in the centre of the window reveal for both the nZEB and LEB. However, this has an insignificant effect on the overall heat demand compared to the influence of window frame thermal transmittance or the influence of the window frame width. Furthermore, it is counteracted by the increasing shading effect of the window reveal once the window is positioned deeper into the wall construction. The negative influence of shading is even more pronounced on the nZEB because of its thicker walls. It is apparent that due to the different overall wall thicknesses, the optimal rel- 
ative installation depth is different on the two versions of the building. However, the distances from the frame midpoint to the façade plane, at which the net heat demand is the lowest, is about the same on both the nZEB and LEB. This is because the influence of the solar gain on the overall building energy balance is greater than the influence of window installation LTT. Thus, it is preferable to install the windows towards the outside of the wall construction, but in such a way that the temperature factor $\mathrm{f}_{\mathrm{Rsi}}$ is within safe limits. Further optimisation of the installation thermal bridge has little effect and one can omit this in the planning phase of the building, thus simplifying the process.

In this paper, a series of simulation energy analyses were performed to determine the effect of window frame parameters and the window installation depth to the net heat demand of a very energy efficient building. The results show that the window frame thermal transmittance and the width of the window frame have noticeable effect on the total energy demand of the building. However, the influence of window installation depth is insignificant. Nevertheless, it is suggested to install the window more to the outside of the wall construction to minimise window reveal and overhang shading. Concurrently it is important to keep the temperature factor within safe limits. If that is ensured, further optimisation work is not particularly beneficial.

This research utilises measurement data from H2020 project No 754177: "NERO - Cost reduction of new Nearly Zero-Energy Wooden buildings in the Northern Climatic Conditions". The research was co-financed by the Estonian Research Council with Personal research funding PRG483 "Moisture safety of interior insulation, constructional moisture and thermally efficient building envelope", Institutional research funding grant IUT1-15, Estonian Centre of Excellence in Zero Energy and Resource Efficient Smart Buildings and Districts, ZEBE, grant TK146 funded by the European Regional Development Fund. The authors would also like to thank Sense OÜ for cooperation of providing data and details about the reference building.

Bülow-Hübe, H. The Effect of Glazing Type and Size on Annual Heating and Cooling Demand for Swedish Offices. Report No. TABK--01/1022, 2001.

Cuce, E., \& Riffat, S. B. A state-of-the-art review on innovative glazing technologies. Renewable and Sustainable Energy Reviews, 2015; 41, 695-714. https://doi.org/10.1016/j.rser.2014.08.084

Directive 2010/31/EU. Directive 2010/31/EU of the European Parliament and of the Council on the energy performance of buildings (recast).

EN ISO 13788:2012. EN ISO 13788:2012 - Hygrothermal performance of building components and building elements - Internal surface temperature to avoid critical surface humidity and interstitial condensation - Calculation methods.

Feist, W. Passive Solarenergienutzung im Passivhaus; Protokollband 13 Energiebilanzen mit dem Passivhaus Projektierungs Paket 1998.

Feist, W., Sariri, V., Ebel, W., \& Baffia, E. Solareinstrahlung in Abhängigkeit von der Orientierung und Verschattung; Protokollband 14 Passivhaus-Fenster 1998.

Feist, W., Schnieders, J., Dorer, V., \& Haas, A. Re-inventing air heating: Convenient and comfortable within the frame of the Passive House concept.
Energy and Buildings, 2005a; 37(11), 1186-1203. https://doi.org/10.1016/j.enbuild.2005.06.020

Feist, W., Schnieders, J., Dorer, V., \& Haas, A. Re-inventing air heating: Convenient and comfortable within the frame of the Passive House concept. Energy and Buildings, 2005b; 37(11), 1186-1203. https://doi.org/10.1016/j.enbuild.2005.06.020

Grynning, S., Gustavsen, A., Time, B., \& Jelle, B. P. Windows in the buildings of tomorrow: Energy losers or energy gainers? Energy and Buildings, 2013; 61, 185192. https://doi.org/10.1016/j.enbuild.2013.02.029

Grynning, S., Time, B., \& Uvsløkk, S. An overview and some reflections on energy saving potentials by heat loss reduction through the building envelope. Project report to be published within the Research Centre on Zero Emission Buildings 2011.

Harmati, N., \& Magyar, Z. Influence of WWR, WG and Glazing Properties on the Annual Heating and Cooling Energy Demand in Buildings. Energy Procedia, 2015; 78, 2458-2463. https://doi.org/10.1016/j.egypro.2015.11.229

Ihm, P., Park, L., Krarti, M., \& Seo, D. Impact of window selection on the energy performance of residential buildings in South Korea. Energy Policy, 2012; 44, 1-9. https://doi.org/10.1016/j.enpol.2011.08.046

\section{Conclusions}

\section{Acknow- ledgment}


ISO 10077-1:2017. ISO 10077-1:2017 - Thermal performance of windows, doors and shutters -- Calculation of thermal transmittance -- Part 1: General.

ISO 10077-2:2017. ISO 10077-2:2017 - Thermal performance of windows, doors and shutters -- Calculation of thermal transmittance -- Part 2: Numerical method for frames.

ISO 10211:2017. ISO 10211:2017 - Thermal bridges in building construction -- Heat flows and surface temperatures -- Detailed calculations.

ISO 13790:2008. EN ISO 13790:2008 Energy performance of buildings - Calculation of energy use for space heating and cooling 2008.

ISO 6946:2017. ISO 6946:2017 - Building components and building elements - Thermal resistance and thermal transmittance - Calculation methods n.d.

Kalamees, T. Critical values for the temperature factor to assess thermal bridges. Proc. Estonian Acad. Sci. Eng, 2006; 12, 3-4.

Kalamees, T., \& Kurnitski, J. Estonian test reference year for energy calculations. Proc. Estonian Acad. Sci. Eng, 2006; 12, 40-58.

LBNL. THERM 7 / WINDOW 7 NFRC Simulation Manual 2017.

Leskovar, V. Ž., \& Premrov, M. An approach in architectural design of energy-efficient timber buildings with a focus on the optimal glazing size in the south-oriented façade. Energy and Buildings, 2011; 43(12), 3410-3418. https://doi.org/10.1016/j.enbuild.2011.09.003

Marino, C., Nucara, A., \& Pietrafesa, M. Does windowto-wall ratio have a significant effect on the energy consumption of buildings? A parametric analysis in Italian climate conditions. Journal of Building Engineering, 2017; 13, 169-183. https://doi.org/10.1016/j.jobe.2017.08.001
Misiopecki, C., Bouquin, M., Gustavsen, A., \& Jelle, B. $P$. Thermal modeling and investigation of the most energy-efficient window position. Energy and Buildings, 2018; 158, 1079-1086. https://doi.org/10.1016/j.enbuild.2017.10.021

Passive House Institute. Passive House Planning Package Version 8 2013. Darmstadt.

Persson, M.-L., Roos, A., \& Wall, M. Influence of window size on the energy balance of low energy houses. Energy and Buildings, 2006; 38(3), 181-188. https://doi. org/10.1016/j.enbuild.2005.05.006

RT | 05.06.2015; 15. Hoone energiatõhususe miinimumnõuded (Minimum requirements for energy performance of buildings).

RT I 19.01.2018; 7. Hoone energiatõhususe arvutamise metoodika (Methodology for calculating the energy performance of buildings).

Sadineni, S. B., Madala, S., \& Boehm, R. F. Passive building energy savings: A review of building envelope components. Renewable and Sustainable Energy Reviews, 2011; 15(8), 3617-3631. https://doi.org/10.1016/j.rser.2011.07.014

Schnieders, J., \& Hermelink, A. CEPHEUS results: measurements and occupants' satisfaction provide evidence for Passive Houses being an option for sustainable building. Energy Policy, 2006; 34(2), 151-171. https://doi. org/10.1016/j.enpol.2004.08.049

Susorova, I., Tabibzadeh, M., Rahman, A., Clack, H. L., \& Elnimeiri, M. The effect of geometry factors on fenestration energy performance and energy savings in office buildings. Energy and Buildings, 2013; 57, 6-13. https:// doi.org/10.1016/j.enbuild.2012.10.035

Winkler, M., Antretter, F., \& Radon, J. Critical discussion of a shading calculation method for low energy building and passive house design. Energy Procedia, 2017; 132, 33-38. https://doi.org/10.1016/j.egypro.2017.09.627

\section{About the Authors}

\section{KRISTO KALBE}

\section{PhD Candidate}

Tallinn University of Technology, Department of Civil Engineering and Architecture, Nearly Zero Energy Buildings Research Group

\section{Main research area}

Energy performance of prefabricated nZEBs

\section{Address}

Ehitajate tee 5 , Tallinn 19086, Estonia

Tel. +37253456148

E-mail: kristo.kalbe@taltech.ee

\section{TARGO KALAMEES}

\section{Professor}

Tallinn University of Technology, Department of Civil Engineering and Architecture, Nearly Zero Energy Buildings Research Group

\section{Main research area}

Building envelope structures; renovation of buildings; hygrothermal behaviour of buildings structures (computer simulations, laboratory experiments, field studies); moisture safety of buildings; boundary conditions for hygrothermal simulations and experiments; building energy consumption and healthy building design; indoor climate and indoor air quality of residential-, office-, and historic buildings

\section{Address}

Ehitajate tee 5, Tallinn 19086, Estonia

Tel. +3726202403

E-mail: targo.kalamees@taltech.ee 